ТУНИК В.Ф.

\title{
ТАБУЛИРОВАННЫЕ СЕКЦИИ ДИСПЕРСИОННЫХ ЛИНИЙ ЗАДЕРЖКИ НИЖНИХ ЧАСТОТ НА ФАЗОВЫХ КОНТУРАХ
}

\author{
Днепропетровский национальный университет железнодорожного транспорта, \\ Украина, Днепропетровск, 49010, ул. Лазаряна 2
}

\begin{abstract}
Аннотация. Отмечены важная роль известных методов аппаратурного анализа спектра низкочастотных сигналов и недостатки полосовых дисперсионных линий задержки (ДЛЗ) для дисперсионного анализа спектра таких сигналов, т.к. существующие таблицы полосовых ДЛЗ не позволяют получать передаточные функции ДЛЗ нижних частот. Показаны возможности составления таблицы секций таких ДЛЗ на фазовых контурах первого и второго порядка. Предложена новая таблица основных параметров и нулей полиномов Гурвица для функции группового времени задержки секций ДЛЗ нижних частот 5, 7, 9, 11, 13 и 15 порядков, каждая из которых получена отдельным Mathcad-документом
\end{abstract}

\begin{abstract}
There is noted essential importance of known methods of hardware analysis of low-frequency signals spectrum and drawbacks of dispersion delay lines (DDL) for dispersion analysis of such signals, and existent tables of pass-band DDLs do not allow to obtain transfer functions of DDL for low frequencies. There are shown possibilities of containing of tables for such DDLs sections on phase circuits of the first and the second orders. There is proposed new table of main parameters and zeros of Hurwitz polynomials for group delay times of DDL sections of low frequencies 5, 7, 9, 11, 13 and 15 orders, each of them is represented with separate Mathcad document
\end{abstract}

Ключевые слова: низкочастотный сигнал, полосовой сигнал, дисперсионная линия задержки, полосовая линия задержки, функция группового времени задержки, фазовый контур первого порядка, фазовый контур второго порядка, полином Гурвица, чебышевский альтернанс, наименьшее отклонение, low-frequency signal, pass-band signal, pass-band dispersion delay line, linear approximating function of group delay time, phase circuit of the first order, phase circuit of the second order, Hurwitz polynomial, Chebyshev alternans, the least deviation

Одной из распространенных задач измерительной техники является задача разработки и реализации эффективных методов аппаратурного анализа частотного спектра электрических сигналов $[1,2]$. Эффективность этих методов зависит от структуры и особенностей отдельных блоков, входящих в измерительное устройство. Простота и точность измерений, а также надежность работы этого устройства должны быть связаны с особенностями исходного сигнала, т.е. измерительное устройство должно быть адекватным измеряемому сигналу. Так для низкочастотных сигналов, основная полоса частот которых сосредоточена дос- таточно близко к началу координат и может содержать нулевую частоту, отдельные блоки анализаторов также должны быть низкочастотными.

Известно большое количество примеров использования результатов аппаратурного анализа спектра именно низкочастотных сигналов при испытании различных машин и механизмов [3], для различных биологических, медицинских, геологических и других исследований явлений природы [4].

Особую роль в создании эффективных измерительных систем имеют различные анализаторы спектра, основным анализирующим 